Vol. 1, No. 2, Mei 2020, pp. 31-40

\title{
PENINGKATAN KETERAMPILAN FISIK MOTORIK HALUS ANAK MELALUI PAPER QUILLING KERTAS KOKORU PADA KELOMPOK B DI RA KALIMOSODO GEDANGAN-MALANG
}

\author{
Dwi Setyo Asih ${ }^{1}$, Norma Ita Sholihah ${ }^{2}$ \\ Program Studi Pendidikan Islam Anak Usia Dini,Fakultas Tarbiyah, \\ Institut Agama Islam Al-Qolam Malang \\ Normaita@alqolam.ac.id
}

Info Artikel

Riwayat Artikel

Diterima : 31 Maret 2020

Disetujui : 30 April 2020
Kata Kunci :

Keterampilan Motorik

Halus, Paper Quilling,

Kertas Kokoru

\section{ABSTRAK}

Abstract: The increasing child's fine motor skills only requires coordination of hand and muscle movements that are done gradually. The aim is to describe the improvement of fine motor skills through kokoru paper quilling paper. Classroom Action Research (Action Research) by applying two cycles through the stages of the planning process, implementation, observation and reflection. Data collection techniques are done by interview, observation, and documentation. Results and discussion on changes in results seen at the end of the first cycle meeting with a percentage of $58.5 \%$, cycle II with a $96 \%$ process. The increase between the two cycles with a percentage of $37.5 \%$ as an increase in fine motor skills of early childhood. This study concluded that the indicators of success in each learning process that emphasizes fine motor skills show a significant increase in the rate of change. The form of change can be seen from the creation of the work through kokoru paper quilling paper.

Abstrak: Peningkatan kemampuan motorik halus anak hanya membutuhkan koordinasi gerak tangan dan otot yang dilakukan secara bertahap. Tujuan untuk mendeskripsikan peningkatan keterampilan motorik halus melalui paper quilling kartas kokoru. Penelitian Tindakan Kelas (Action Research) dengan menerapkan dua siklus melalui tahap proses perencanaan, pelaksanaan, pengamatan dan refleksi. Teknik pengumpulan data dilakukan dengan wawancara, observasi,dan dokumentasi. Hasil dan pembahasan pada perubahan hasil yang terlihat pada akhir pertemuan siklus I dengan prosentase $58,5 \%$, siklus II dengan prosesntase $96 \%$. Peningkatan antar kedua siklus dengan prosentase $37,5 \%$ sebagai peningkatan keterampilan motorik halus anak usia dini. Penelitian ini disimpulkan indikator keberhasilan dalam setiap proses pembelajaran yang menekankan keterampilan motorik halus terlihat angka perubahan peningkatan yang sangat signifikan. Bentuk perubahan terlihat dari kreasi hasil karya melalui paper quilling kertas kokoru. 


\section{PENDAHULUAN}

Kemampuan aspek perkembangan merupakan kemampuan meliputi kemampuan fisik motorik, kemampuan kognitif, kemampuan bahasa, kemampuan sosial emosional, kemampuan nilai agama dan moral, dan kemampuan seni. Tugas mengembangkan kemampuan anak usia 5-6 tahun dapat dilandasi dari lembaga pendidikan keluarga. Pada dasarnya anak masih memerlukan perhatian secara utuh, terutama perhatian penuh akan mempengaruhi fase perkembangan. Peneliti disini memfokuskan pada kemampuan fisik motorik halusnya. Menurut Hurlock, (2005) mengatakan bahwa kemampuan aspek fisik motorik halus maupun kasar sebagai pengendali jasmaniah yang terorganisir pada kinerja pusat syaraf, urat syaraf dan otot yang berkoordinasi dengan bagian anggota tubuh seperti tangan dan mata. ${ }^{1}$ Sehingga, salah satu fokus terpenting terhadap perkembangan fisik motorik halus ketika proses penerapannya melalui konsep bermain dalam berkreatifitas sebagai bekal keterampilan anak. Selain itu, proses menanamkan keterampilan yang dibutuhkan biasa dilakukan oleh pendidik. Ketika di dalam proses belajar kelas seperti menulis, menggambar, melukis, mewarnai. Sehingga, membutuhkan inovasi baru dalam prose belajar anak usia 5-6 tahun.

Pada usia 5-6 tahun anak berada pada tahap keemasan (golden age). Dimana, tahap ini anak sudah bisa memainkan imajinasinya dalam berkreasi dan mengasah kreatifitas anak didik. Ciri perkembangan fisik motorik halus pada tahap perkembangan anak 5-6 tahun meliputi kemampuan dalam melipat, menggambar, menggunting, menempel, mencocok. Kemampuan anak dapat dipelajari dari orang tua maupun lingkungan sekolahnya. Masa kanak-kanak sering disebut dengan masa bermain, Oleh karena itu, kegiatan belajar anak harus dilakukan dengan belajar seranyanya bermain. ${ }^{2}$ Hal tersebut menjadi kunci utama dalam mengembangkan aspek fisik motorik halus tanpa adanya tekanan dalam jiwa, dan perasaan anak. Sehingga, anak lebih cenderung menikmati proses belajar yang sesuai dengan usia anak.

Proses belajar yang mengarah pada keterampilan anak yang terlihat masih rendah meliputi 13 anak dari 26 peserta didik dalam menyelesaikan tugas yang belum rapi, dan menggunting pola masih belum tepat. Begitupula, kegiatan mewarnai juga masih belum rapi. Keterampilan fisik motorik halus pada anak disebabkan dari beberapa faktor adanya pendampingan belajar dalam mengembangkan fisik motorik halus melalui orang tua yang masih kurang. Sehingga, keterampilan fisik motorik halus anak belum berkembang secara maksimal. Jika perkembangan fisik motorik halus anak terganggu maka akan mempengaruhi aspek tumbuh kembang yang lainnya. Oleh karena itu, melatih kemampuan fisik motorik halus anak membutuhkan ketekunan, kesabaran dan pengarahan secara penuh pada setiap perkembangan anak.

\footnotetext{
${ }^{1}$ Elizabeth B. Hurlock, Perkembangan Anak Jilid 1 (Jakarta: Erlangga, 2005), halaman 150.

${ }^{2}$ Yeni Rachmawati \& Euis Kurniati, Strategi Mengembangkan Kreativitas Pada Anak Usia Taman Kanakkanak (Jakarta: Kencana, 2010), halaman 1.
} 
Kompetensi PAUD tentang standart perkembangan fisik motorik anak pada usia 5-6 tahun. Terlihat anak dapat menggunakan anggota tubuh untuk pengembangan fisik motorik kasar atau halus ${ }^{3}$. Idealnya, pada rentang usia 5-6 tahun anak mampu melakukan gerakan dan kegiatan yang berhubungan dengan perkembangan fisik motorik halus secara baik. Sehingga, anak mampu melakukan koordinasi pikiran, mata dan tangan secara baik sesuai dengan tahap-tahapnya. Oleh karena itu, diperlukan stimulus yang mampu mengembangkan kemampuan yang dimiliki oleh anak usia dini guna meningkatkan keterampilan fisik motorik halus anak.

Rancangan dalam proses belajar anak yang dapat memberikan stimulus secara efektif sebagai upaya mengembangkan kemampuannya melalui proses pembelajaran dengan menggunakan paper quilling kertas kokoru. Dimana, media menjadi salah satu sarana-prasana untuk berkreatifitas. Selain itu, tujuan kegiatan untuk meningkatkan keterampilan fisik motorik halus anak. Paper quilling kertas kokoru merupakan bahan yang sangat aman dan mudah digunakan dalam kegiatan untuk melatih koordinasi mata, tangan dan otak pada anak usia dini. ${ }^{4}$ Kegiatan ini terfokus pada teknik menggulung kertas, merekatkan selain itu mengeksplorasi kreatifitas anak dari kegiatan yang dilakukan.

Kegiatan ini sangat berkontribusi dalam meningkatkan keterampilan dasar anak dengan menggunakan bahan kertas kokoru. Selain itu, tekstur kertas kokoru berbentuk gelombang dapat mempermudah anak dalam mempergunakannya. Maka, manfaat adanya media tentunya anak akan terangsang kemampuan motoriknya secara lincah dalam berkreatifitas. Kelicahan tangan yang dibutuhkan dapat memberikan stimulus pada kinerja otak kanan dan kiri, serta kemampuan panca indra dalam penglihatan menjadi terkoordinasi untuk anak lebih tenang dan berkonsentrasi. Disinilah, peranan penting pendidik dalam mengontrol, membimbing dan mengarahkan teknik dalam membuat keterampilan dari kertas kokoru. Ketika menerapkan kegiatan tersebut cukup membuat anak menjadi lebih terampil dan kemampuan motorik halus.

Tujuan penelitian ini untuk mendeskripsikan keterampilan fisik motorik halus anak melalui paper quilling kertas kokoru pada anak. Untuk mendeskripsikan media paper quilling kertas kokoru dalam meningkatkan keterampilan fisik motorik halus anak pada kelompok B di RA Kalimosodo Gedangan-Malang

\section{METODE}

Penelitian yang digunakan berupa Penelitian Tindakan Kelas (action research). Menurut Arikunto (2010) mengatakan bahwa PTK memerlukan 3 tahap sesuai dengan prosedure yang berbentuk pra tindakan siklus, siklus I dan siklus II

\footnotetext{
${ }^{3}$ Depdiknas (2007). Pedoman Pembelajaran Bidang Pengembangan Motorik Halus di Taman Kanak-kanak. Jakarta: Direktorat Pembinaan Taman Kanak-kanak dan sekolah Dasar.

${ }^{4}$ Molly (2015). Miniatur Paper Quilling. Jakarta: PT Gramedia Pustaka Utama.
} 
dalam tahap menggunakan metode penelitian PTK meliputi planning, action \& observation, dan reflection. ${ }^{5}$ Kemudian, berputar lalu terjadi perbaikan atau peningkatan yang diharapkan. Penelitian ini dilaksanakan selama enam kali pertemuan.

Penelitian tindakan kelas merupakan kajian sistematik dari upaya perbaikan, pelaksanaan, praktek oleh sekelompok pendidik dengan melakukan tindakan-tindakan dalam pembelajaran. Berdasarkan refleksi yang dilakukan sebagai evaluasi kegiatan, dimana peneliti akan menemukan hasil data secara kogkret dari proses tindakan-tindakan tersebut yang telah dilakukan. ${ }^{6}$

Subyek penelitian dalam penelitian ini adalah anak Kelompok B di RA Kalimosodo Gedangan-Malang yang berjumlah 26 anak yang terdiri dari 6 anak perempuan, 20 anak laki-laki. Berdasarkan identifikasi permasalahan yang terjadi terdapat 12 anak yang digunakan sebagai sampel untuk dilakukan pengamatan lebih lanjut dalam meningkatkan keterampilan motorik halus anak. Namun, peneliti melibat keseluruhan anak didik dalam mengikuti pembelajaran di setiap penerapan siklusnya.

Teknik pengumpulan data dilakukan dengan wawancara, observasi, dokumentasi diketahui bahwa selama melaksanakan pengamatan dalam kegiatan pembelajaran anak kelompok B di RA Kalimosodo Desa Sumberrejo GedanganMalang. Dimana, pendidik memfokuskan pada kemampuan motorik halus anak yang menekankan pada keterampilan dasar terhadap anak dengan menggunakan paper quilling kertas kokoru. Agar dapat membangun pengalaman-pengalaman baru anak.

Analisis data menggunakan (mixmethod). Dimana, data yang dihasilkan berupa kualitatif-kuantitatif yang menggambarkan bentuk fakta sesuai data secara deskriptif yang diperoleh sebagai tujuan penelitian ${ }^{7}$. Proses mendeskripsikan kemampuan anak didik terfokus dalam meningkan keterampilan motorik halusnya. Selain itu, proses tersebut dapat memperoleh data satistik dari respon anak didik ketika mengikuti kegiatan keterampilan membuat hasil karya dari paper quilling kertas kokoru selama proses aktivitas berlansung berdasarkan tahap siklus I dan siklus II dengan fokus indikator pada aspek menggulung, aspek kemampuan merekatkan, aspek menempel, dan mengembangkan aspek eksplorasi untuk kemampuan imajinasinya dalam berkreasi.

\section{HASIL DAN PEMBAHASAN}

Pada hasil penelitian yang dilakukan melalui tahap setiap siklus. Akan dilakukan proses analisa untuk memunculkan rata-rata hasil akhir pada siklus I dan siklus II. Proses disini dilakukan setiap siklusnya dengan 3 kali pertemuan. Sehingga, peneliti melakukan 6 kali pertemuan dalam dua siklus pada aktivitas

\footnotetext{
${ }^{5}$ Arikunto, S.(2010). Prosedur Penelitian Suatu Pendekatan Praktik. Jakarta: Rineka Cipta

${ }^{6}$ Sugiyono (2010). Metode Penelitian Pendidikan. Bandung: Alfabeta

${ }^{7}$ Wardhani, IGAK (2014). Penelitian Tindakan Kelas. Jakarta: Universitas Terbuka 
paper quilling melalui bahan kertas kokoru untuk mengasah keterampilan fisik motorik halus pada anak kelas B. Aktivitas dalam mengasah keterampilan fisik motorik halus anak tentu tidak mudah, melihat karakteristik anak yang berbedabeda. Serta, kondisi perasaan anak yang terkadang tidak stabil. Sehingga, membutuhkan inovasi baru dalam mengembangkan keterampilan motoriknya melalui bahan dari kertas kokoru. Agar memperlancar kegiatan belajar anak. Selain itu, membuat anak tetap senang ketika belajar di sekolah.

Kegiatan siklus I pertemuan 1 yang dilakukan senin, 22 januari 2020 , dengan tema alam semesta dan sub tema benda langit. Selain itu, peneliti merancang indikator sebagai penilaian terhadap peningkatkan keterampilan fisik motorik halus pada anak, meliputi kemampuan menggulung dan kemampuan mengelem atau merekatkan. Indikator tersebut akan melihatkan kemampuan anak berdasarkan hasil yang telah dituntaskan dan belum tuntas. Selain itu, pendidik melakukan evaluasi kegiatan secara lebih lanjut yang menjadi rendahnya angka ketuntasan di setiap pertemuan siklus. Kemudian dilakukan tindakan dalam memperbaiki pada pertemuan berikutnya. Sehingga, data yang dihasilkan akan maksimal dalam meningkatkan keterampilan fisik motorik halus anak.

Rincian hasil data pada siklus 1 pertemuan 1 berdasarkan indikator keberhasilan yang telah terhitung rata-rata hasil akhir penilaian dari dua indikator meliputi kemampuan menggulung dan kemampuan mengelem atau merekatkan secara tepat. Data yang diperoleh dari penerapan proses keterampilan fisik motorik halus anak yang memiliki ketuntasan dengan prosentase 37,5\% dengan jumlah 9 anak. Sedangkan, proses belajar anak yang belum tuntas memiliki prosentase 62,5\% dengan jumlah 17 anak. Hasil tersebut telah dilakukan evaluasi kegiatan belajar anak, bahwasannya anak-anak sudah merasa antusias dengan kegiatan yang dipersiapkan oleh guru. Namun, masih kesulitan ketika mempraktekkan teknik menggulung dari kertas kokoru secara tepat.

Rincian hasil data pada siklus I pertemuan II yang dilakukan selasa, 23 januari 2020, dengan tema bintang kecil. Masih dengan indikator keberhasilan yang sama dengan pertemuan I, meliputi kemampuan menggulung dan kemampuan mengelem atau merekatkan. Disini, anak-anak memulai kemambali keterampilan fisik motoriknya dengan membuat bentuk bintang kecil dan besar melalui kertas kokoru untuk menganalisa hasil perkembangan kemampuan anak dalam berkarya. Hasil yang diperoleh dari tuntas dan belum tuntasnya dalam proses belajar anak. Hasil data berdasarkan dua indikator tersebut ketuntasan mencapai 41,5\% dengan jumlah 12 anak, sedangkan yang belum tuntas mencapai 58,5\% dengan jumlah 14 anak. Hasil tersebut dapat di evaluasi kegiatan adanya keterlambatan dalam menyelesaikan tugas dan guru kurang memotivasi anak untuk segera menyelesaikan.

Rincian hasil data siklus I pertemuan III yang dilakukan rabu 24 januari 2020, dengan tema ambilkan bulan. Masih dengan indikator keberhasilan yang sama, meliputi kemampuan menggulung dan kemampuan mengelem atau 
merekatkan. Data di hitung berdasarkan tuntas dan belum tuntas. Rincian data berdasarkan dua indikator tersebut ketuntasan mencapai 58,5\% dengan jumlah 14 anak, sedangkan yang belum tuntas mencapai 41,5\% dengan jumlah 12 anak. Disini, terlihat adanya peningkatan bahwasannya menciptakan hasil karya dalam memberikan stimulus pada keterampilan anak dengan teknik yang sama namun dengan tema yang berbeda dapat menunjang aspek perkembangan motorik halus melalui media yang aman dari bahan kertas kokoru memiliki kemudahan, kemenarikan, keefektif dan keefisien dalam proses belajar serayanya bermain untuk anak kelompok B. Dikarenakan pada hasil evaluasi kegiatan pertemuan III telihat beberapa anak dapat menggulung kertas kokoru dengan bentuk bulan sesuai dengan instruksikan. Namun, evaluasi perbaikan yang perlu di analisis oleh pendidik teruma dalam memberikan penjelas terhadap anak masih terlalu cepat. Sehingga, peneliti melakukan tahap berikutnya di siklus II untuk memperoleh hasil secara maksimal untuk memperbaiki yang telah di evaluasi dari siklus I.

Hasil hasil data pada siklus II pertemuan I yang dilakukan kamis, 25 januari 2020, dengan menggunakan paper quilling membuat bentuk pola bumi dan finger painting bentuk gambar bumi. Kemudian, anak-anak di ajak menulis kata bumi dari hasil karya yang telah di buat. Indikator keberhasilan pada kemampuan menggulung dan kemampuan berkreasi terlihat hasil yang sangat signifikan. Rincian data berdasarkan indikator keberhasilan pada kemampuan menggulung dan berkreasi memiliki ketuntasan dengan prosesntase mencapai $66,5 \%$ dengan jumlah 16 anak. Sedangkan, indikator keberhasilan pada kemampuan menggulung dan berkreasi yang belum tuntas memiliki prosentase mencapai 33,5\% dengan jumlah 10 anak. Hasil evaluasi kegiatan telah terlihat anak memiliki antusias yang sangat tinggi dalam melaksanakan pembelajaran melalui media yang telah disediakan oleh pendidik untuk melatih keterampilan motorik halus anak.

Hasil data pada siklus II pertemuan II dilakukan pada jum'at, 26 januari 2020 dengan kegiatan menulis huruf hijaiyah (bahasa arabnya awan), mengurutkan gambar awan dari yang terkecil sampai yang terbesar, paper quilling titik-titik air hujan di bawah gambar awan. Terbukti hasil data berdasarkan indikator keberhasilan pada kemampuan menempel dan berkreasi memiliki ketuntasan dengan prosentase mencapai $75 \%$ dari jumlah 18 anak. Sedangkan, indikator keberhasilan pada kemampuan menempel dan berkreasi memiliki ketuntasan dengan prosentase mencapai $25 \%$ dari jumlah 8 anak. Hasil evaluasi kegiatan terhadap anak sudah mulai cepat dalam membuat lima titik-titik air hujan dari paper quilling kertas kokoru. Namun, pada waktu menempel penataannya masih ada yang menggerombol dan Anak memiliki rasa antusias yang tinggi dalam melaksanakan kegiatan pembelajaran dengan perasaan senang.

Hasil data pada siklus II pertemuan III dilakukan pada sabtu, 27 januari 2020 dengan kegiatan menghias pigora tempat foto presiden menggunakan hiasan paper quilling kertas kokoru dengan membentuk motif hati, menulis nama presiden republik Indonesia, menggunting dan menyusun kepingan huruf yang membentuk 
kata "Presiden". Indikator keberhasilan kemampuan berkreasi sesuai dengan imajinasinya, sehingga memiliki nilai tuntas dan belum tuntas dari kegiatan yang telah dilakukan. Hasil data dari indikator keberhasilan kemampuan berkreasi sesuai dengan imajinasinya memiliki ketuntasan yang mencapai prosentase 96\% dari 24 anak. Sedangkan, hasil data dari indikator keberhasilan kemampuan berkreasi sesuai dengan imajinasinya memiliki belum tuntas yang mencapai prosentase $8 \%$ dari 2 anak. Hasil evaluasi kegiatan pada anak, terlihat senang dalam melaksanakan kegiatan dengan menggunakan paper quilling kertas kokoru, untuk berkreasi membuat pola atau bentuk hati. Karena dirasa berbeda dari yang sebelumnya dan Anak-anak sudah tidak banyak mengalami kesulitan atau meminta bantuan dari guru. Dan gurupun memberi reward bagi anak yang sudah mandiri dalam menyelesaikan kegiatan paper quilling.

Berdasarkan hasil data setiap pertemuan pada siklus I dan siklus II , terbukti bahwasannya dasar dari peningkatan kemampuan motorik halus anak . terlihat dari kemampuan guru dalam merancang sebuah kegiatan yang dapat menciptakan hasil karya. Penanaman keterampilan dasar pada anak mampu menjadi bekal anak untuk mengembangkan kreatifitasnya yang di mulai sejak dini. Terlihat dari hasil data yang telah di kelolah untuk mendeskripsikan peningkatan keterampilan motorik halus anak melalui paper quilling kertas kokoru berdasarkan ketuntasan dari kemampuan yang dihasilkan oleh anak didik. Hal tersebut dipaparkan pada tabel 4.1, sebagai berikut:

Tabel 4.1 Hasil persentase peningkatan di antara siklus I dan siklus II ${ }^{8}$

\begin{tabular}{llllll} 
& \multicolumn{2}{c}{ Siklus I } & \multicolumn{2}{c}{ Siklus II } & \begin{tabular}{l} 
Peningkatan \\
hasil data \\
\cline { 2 - 6 }
\end{tabular} \\
\cline { 2 - 6 } & & & & & $\begin{array}{l}\text { ketuntasan } \\
\text { di antara } \\
\text { siklus I dan } \\
\text { siklus II }\end{array}$ \\
\hline I & $37,5 \%$ & 9 & $66,5 \%$ & 16 & $29 \%$ \\
\hline II & $41,5 \%$ & 12 & $75 \%$ & 18 & $25 \%$ \\
\hline III & $58,5 \%$ & 14 & $96 \%$ & 24 & $37,5 \%$ \\
\hline $\begin{array}{l}\text { Jumlah dari } \\
\text { prosentase } \\
\text { keseluruhan }\end{array}$ & $137,5 \%$ & & $237,5 \%$ & & $100 \%$ \\
\hline
\end{tabular}

Hasil dari jumlah prosentase keseluruhan yang telah terhitung antara siklus I dan siklus II pada setiap pertemuan, terlihat rincian data setiap siklusnya berdasarkan tabel 4.1 mengalami peningkatan yang sangat signifikan dengan prosentase $100 \%$ dikategorikan sangat tinggi. Dimana, angka prosentase menyimpulkan bahwa keberhasilan pembelajaran dalam meningkatkan keterampilan fisik motorik halus anak melalui hasil karya dari paper quilling kertas kokoru menjadi sangat efektif dan efisien. Ketika proses pembelajaran yang dapat mendasari anak untuk mengembangkan kreatifitasnya dari peningkatan

${ }^{8}$ Tabel 4.1 Hasil persentase peningkatan di antara siklus I dan siklus II 
kemampuannya. Sehingga, hasil yang diperoleh akan terlihat melalui bagan 4.1, sebagai berikut :

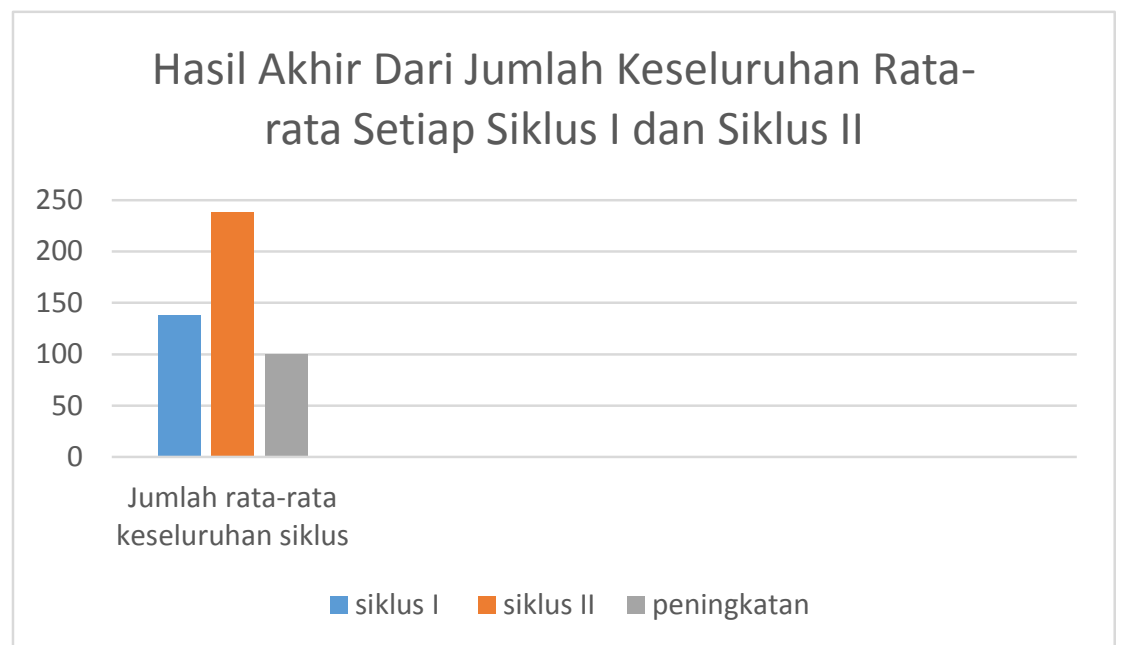

\section{Bagan 4.1 Grafik rata-rata dari hasil keseluruhan pada peningkatan antara siklus I dan siklus II ${ }^{9}$}

Pada paparan hasil melalui bagan 4.1 sudah terlihat peningkatan jumlah hasil keseluruhan dari siklus I dengan jumlah prosentase $137,5 \%$ yang terhitung pada hasil yang diterapkan dengan tiga kali pertemuan dengan tema pembelajaran yang berbeda. Selain itu, hasil ketuntasan / kemampuan anak dalam meningkatkan keterampilan telah mengalami peningkatan. Meskipun dalam proses evaluasi masih ada beberapa anak mengalami kesulitan. Namun, hal tersebut tidak dijadikan permasalahan dikarena proses kemampuan anak satu dengan yang lain sangat memiliki keunikan. Sehingga, butuh ketelatenan dan kesabaran pendidik dalam memberikan pengarahan ketika proses pembelajaran berlangsung. Sedangkan, peningkatan dari rata-rata hasil keseluruhan pada siklus II mengalami peningkatan dengan jumlah prosentase $237,5 \%$ yang terhitung pada hasil yang diterapkan dengan tiga kali pertemuan dengan kegiatan pembelajaran yang berbeda. Disini, peningkatan ketuntasan anak memberikan respons yang sangat baik sebagai penunjang keterampilan motorik halus anak yang dipaparkan pada tabel 4.1. Hasil akhir peningkatan antara kedua siklus memiliki prosentase $100 \%$ termasuk kategori sangat tinggi. Dimana, hasil yang ditunjukkan memberikan keberhasilan pendidik dalam meningkatkan keterampilan aspek motorik halusnya.

\section{SIMPULAN DAN SARAN}

Berdasarkan paparan data yang dihasilkan melalui proses penrapakannya dapat disimpulkan bahwa Pertama, penerapan paper quilling kertas kokoru di kelompok B RA Kalimosodo Sumberrejo Gedangan terhadap kompetensi dasar anak telah banyak membantu pencapaian indikator-indikator yang akan dicapai setiap harinya. Penerapan ini dilakukan dengan mengajak anak melakukan praktik langsung melaui kegiatan paper quilling kertas kokoru guna meningkatkan

\footnotetext{
${ }^{9}$ Bagan 4.1 Grafik rata-rata dari hasil keseluruhan pada peningkatan antara siklus I dan siklus II 
keterampilan motorik halus anak. Anak dapat melakukan kegiatan sesuai dengan aspek kreatifitas dan keterampilan yaitu kemampuan menggulung kertas dan kemampuan mengelem atau merekat.

Kedua, diterapkannya paper quilling kertas kokoru di kelompok B RA Kalimosodo Sumberrejo Gedangan, kemampuan motorik halus anak meningkat. Hasil penelitian menunjukkan bahwa prosentase keterampilan motorik halus anak pada hasil akhir siklus I mengalami peningkatan dengan rata-rata keseluruhan dengan jumlah prosentase $137,5 \%$. Sedangkan, peningkatan keterampilan motorik halus anak pada rata-rata keseluruhan dari hasil akhir siklus II dengan jumlah prosentase $237,5 \%$ dan sesuai dengan yang diharapkan masuk kriteria sangat tinggi dengan prosentase $100 \%$ hasil terhitung dari peningkatan rata-rata keseluruhan dari hasil siklus I dan siklus II.

Berdasarkan kesimpulan yang peneliti paparkan di atas, maka perlu adanya saran dan perbaikan yang mendukung. Adapun saran-saran dalam penggunaan media untuk kegiatan paper quilling, kertas sebaiknya kertas yang digunakan adalah kertas yang sesuai bagi anak (tidak terlalu tebal maupun terlalu tipis dan lebih baik lagi jika bertekstur/ bergelombang). Sehingga, mempermudah dalam proses menggulung. Pemilihan kertas sebaiknya menggunakan kertas berwarna menarik agar anak semakin tertarik mengikuti kegiatan pembelajaran paper quilling. Kegiatan paper quilling kertas kokoru ini, sebaiknya dilakukan secara berkelanjutan, dalam artian tidak hanya sebatas untuk penelitian saja untuk mencapai tujuan pada keterampilan motorik halus anak bisa berkembang sangat optimal. Peranan pendidik dapat memberikan reward berupa motivasi kepada anak, agar mereka lebih semangat dalam mengikuti kegiatan pembelajaran.

Motivasi yang diberikan kepada anak semakin meningkatkan kesadaran akan pentingnya belajar sejak usia dini dan mempersiapkan pembelajaran dengan tingkat kesulitan yang lebih tinggi. Selain itu, kejasama pendidik dan orang tua, dapat menjadi peranan penting dalam mengontrol, mengarahkan dan memberikan pendampingan belajar terhadap perkembangan keterampilan motorik halus anak dengan menciptakan kreatifitas dari bahan sederhana ketika dilingkungan rumah.

\section{DAFTAR RUJUKAN}

Arikunto, S.(2010). Prosedur Penelitian Suatu Pendekatan Praktik. Jakarta: Rineka Cipta

Depdiknas (2007). Pedoman Pembelajaran Bidang Pengembangan Motorik Halus di Taman Kanak-kanak. Jakarta: Direktorat Pembinaan Taman Kanakkanak dan sekolah Dasar.

Hurlock, Elizabeth B (2005). Perkembangan Anak Jilid 1. Jakarta: Erlangga.

Rachmawati, Y \& Euis, K., (2010). Strategi Mengembangkan Kreativitas Pada Anak Usia Taman Kanak-kanak. Jakarta: Kencana

Molly (2015). Miniatur Paper Quilling. Jakarta: PT Gramedia Pustaka Utama. 
Sugiyono (2010). Metode Penelitian Pendidikan. Bandung: Alfabeta

Wardhani, IGAK (2014). Penelitian Tindakan Kelas. Jakarta: Universitas Terbuka. 